\title{
8 MUSLIM AND CHRISTIAN CONTESTATION OVER THE ENTRENCHMENT OF THE KADHI COURTS IN THE CONSTITUTION OF KENYA: CHALLENGING THE PRINCIPLE OF A SECULAR STATE
}

\section{Hassan Juma Ndzovu ${ }^{1}$}

\section{INTRODUCTION}

Islam and Christianity are the two religions that dominate the religious realm in Kenya. Generally, there are conflicting reports regarding the religious affiliation of Muslims and Christians in the country. Statistics on religious population tend to be varied depending on the source of information. The politics of numbers is contested between the Muslims and the Christians segments of the population. ${ }^{2}$ The figures from the 2009 national population census, which had questions dealing with the religious affiliation of a person, indicated Christians to be around $81 \%$ of the population and Muslims about $11 \%{ }^{3}$ Muslims have rejected this figure and viewed it as a grand design by the government to deprive them of adequate resources and positions of power in a government in favour of Christians. ${ }^{4}$ Being a minority religious group vis-à-vis Christians, Muslims have viewed their Christian counterparts with suspicion thereby critical of every move and statement made by either the government or their non-Muslims compatriots.

Despite the Muslims' suspicion, they have always collaborated with their Christian compatriots to participate in their country's political discussions on matters of national interest. For instance, during the reign of Daniel arap Moi (1978-2002), the religious sector and professional bodies jointly challenged his alleged repressive government, leading to the ushering in of multi-party politics

1 Hassan Ndzovu is a Senior Lecturer in the Department of Philosophy, Religion and Theology, Moi University, Kenya.

2 Kettani AM. 1982. "Muslim East Africa: An Overview", Journal Institute of Muslim Minority Affairs 4(1,2):104-119; Constantin F. 1993. “Leadership, Muslim Identities and East African Politics", in Brenner L (ed). Muslim Identities and Social Change in Sub-Saharan Africa. London: Horst and Company; Bakari M. 1995. "Muslim and Politics of Change in Kenya", in Bakari M and Yahya SS (eds). Islam in Kenya. Nairobi: MEWA Publication; Cruise DB. 1995. “Coping With the Christians: The Muslim Predicament in Kenya", in Hansen HB and Twaddle M (eds). Religion and Politics in East Africa. London: James Currey.

3 See Kenya National Bureau of Statistics, "Overview of 2009 Census". Online at: http://www.knbs.or.ke/index.php?option=com_content\&view=article\&id=14 9\&Itemid=635; Jamah A. 2010. "Over 27 Million Kenyans are Christians”, The Standard, 1 September: 11.

4 2010. "Census Uproar: Leaders Dismiss Alleged 4.3 Million Figure for Muslims", Friday Bulletin: The Weekly Muslim News Update, 3 September:1, 3. 
in early 1990s. ${ }^{5}$ This opening of democratic space was followed by the agitation for a new constitution, which culminated in the enactment of the Constitution of Kenya Review Commission (Amendment) Act in 1997. Doubting the government impartiality in the constitution-making process, religious groups came together under the banner of the Ufungamano Initiative to assist the government in producing a new constitution for the country. Since 2010, the country has witnessed Christian and Muslim religious leaders come together in an (un)holy alliance to dominate the public debate in castigating homosexual relations. The perceived unity of the various religious traditions is sometimes challenged when the issue at hand does not bind them to shared community of believers. Thus, when it comes to pursuing objectives that are not related to all the religious communities, the religious sector tends to abandon their shared religious unity and appear divided along specifically religious lines. This situation shows a dialectic play of factors, some creating unity and others creating division - and the case of Kadhi Courts has fallen into the category of divisive forces.

The entrenchment of the Kadhi Courts in the Kenyan Constitution has been a subject matter of dispute between Muslims and Christians in Kenya. The main issue under scrutiny in this chapter is the interplay of religion and state matters in Kenya, as demonstrated through the institution of the Kadhi Courts. As a result, my contribution in this chapter examines the legality of the Kadhi Courts in the Kenyan Constitution, arguing that the entrenchment of the Kadhi Courts in the country's Constitution did not contravene the secular state premise of the Constitution. To establish the above thesis, the chapter addresses the following questions: What are the Kadhi Courts under the Kenyan Constitution? How constitutional are the Kadhi Courts? And how congruent are they with Kenya's secularity principle under the Constitution? While answering the foregoing questions, the chapter seeks to attain two main objectives: (i) to understand the constitutionality or otherwise of the Kadhi Courts, and (ii) to understand their (in)-compatibility within the secular state premise in the Kenyan Constitution.

Whereas the policy in secular states is supposed to be based on the formal distinction between religion and the state, this does not imply complete absence of interaction and influence between religion and politics. In secular states, the incorporation of religion into politics varies and can be described as either moderate or even very little. ${ }^{6}$ The genesis of the word secularism is attributed

5 The active professional bodies that aligned with the religious sector together with opposition political organisation to condemned Moi's alleged poor leadership included the Law Society of Kenya (LSK), THE Justice and Peace Convention (JPC), and the National Ecumenical Civic Education Programme (NECEP).

6 Adams CJ. 1982. "Background of the Contemporary Islamic Resurgence", Islamic Order Quarterly 4(1); Mazrui AA. 1993. "African Islam and Comprehensive Religion: Between Revivalism and Expansion", in Alkali N et al. (eds). Islam in Africa. Ibadan: Spectrum; Hansen HB and Twaddle M (eds). 1995. Religion and Politics in East Africa. London: James Currey; Haqnadvi SH. 1995. Islamic Fundamentalism: Theological Liberation and Renaissance. Durban: The Centre for 
to, the late nineteenth-century British atheist and freethinker, George Jacob Holyoake (1817-1906) in describing a social order independent of religion, but where all religions are respected equally. ${ }^{7}$ In Holyoake's view, secularism is not a negation of religion, but argues that societies should not entirely rely on "theological premises and faith", which are "supernatural and non-scientific" in seeking truth. ${ }^{8}$ This view can be contrasted by JC Barnet, who posited that "secularism is life organized apart from God, as though God did not exist." ${ }^{9}$ Barnet's observation of secularism envisaged a society in which religion had no place in public life. A similar "anti-religious element to secularism" is described by Holyoake's contemporary, an atheist and political activist, Bradlaugh $\mathrm{H}$ Bonner (1833-1891), who considered the influence the Church held over certain governments in Europe "as a threat to freedom of all kinds."10

A study of the evolution of secularism reveals a long history of competition between religion and the state. The secular political authorities of Europe resented the encroachment of the papacy into the political domain, setting a bitter struggled between the two institutions. The outcome of the struggle was the Church agreeing to confine its activities to spiritual matters, according the state independence to deal with political affairs. ${ }^{11}$ This policy of non-interference has been adopted in the constitutions of a number of countries in the world today, including Kenya, which declare themselves explicitly or implicitly to be secular states.

At this stage a question can be asked: what are the principles of a secular state? It is not easy to ascertain the ingredients of a secular state, as they differ from one state to the other. This is attributed to the variant interpretations of the concept of secularism which secular states incorporate into their constitutions. There is no consensus on whether secularism is anti-religious or non-religious in essence, and as a consequence there are many variations of a secular state. ${ }^{12}$ Religious studies scholars, Carl F Hallencreutz and David Westerlund argue that a secular state "presupposes that there is at least a formal separation between religion and state", in which the liberal form of this policy respects religion as an important resource in society and accord individual as well as corporate

Islamic, Near and Middle Eastern Studies Publication; Oyediran O and Agbaje A (eds). 1999. Nigeria: Politics of Transition and Governance 1986-1996. Basford: Russell Press Ltd; Lincoln B. 2003. Holy Terrors: Thinking about Religion after September 11. Chicago: University of Chicago Press.

7 Balasubramanian M. 1980. Nehru: A Study of Secularism. New Delhi: Uppal Publishing House; Monshipouri M. 1998. Islamism, Secularism and Human Rights in the Middle East. London: Lynne Rienner.

8 Beard RT et al. 2013. "Secularism, Religion, and Political Choice in the United States", Politics and Religion 6(4):1-25.

9 Balasubramanian, Nehru: A Study of Secularism, 2-3.

10 Beard et al., "Secularism, Religion, and Political Choice in the United States", 1-25.

11 Balasubramanian, Nehru: A Study of Secularism.

12 Kuru AT. 2007. "Passive and Assertive Securalism: Historical Conditions, Ideological Struggles, and State Policies toward Religion", World Politics 59:568-595. 
religious freedom. ${ }^{13}$ On the other hand, the Marxist version of secularism is an ideology that views religion negatively and has the core objective of banishing religion from people's consciousness, presumably leaving them with only politics. ${ }^{14}$ Nevertheless, such policies have not been successful, as citizens have usually risen to challenge them.

When Kenya attained independence in 1963, the primary concern of the postindependence leaders was to build a strong nation out of the numerous ethnic groups in the country. As a consequence, the country adopted a constitution that did not elevate any religion to the status of a state religion. An examination of the various sections of the Kenyan Independence Constitution reveals the nature of the secular state that obtains in Kenya. Though the Independence Constitution did not specifically stipulate that Kenya is a secular state, as Article 1 simply described Kenya as "a sovereign Republic", most Kenyans understood their country to be secular one. ${ }^{15}$ Arguably, this view is based on the two core principles that define a secular state: (1) lack of institutional religious control of the legal and judicial processes; (2) establishment of neither an official religion nor atheism. ${ }^{16}$

However, the form of secularism observed in Kenya is not anti-religious, as Article 78 of the Independence Constitution provided for freedom of religion to all citizens, guaranteed under the general protection of freedom of conscience. Under this section of the Constitution, the state is not allowed to interfere or control religious affairs. Clearly, the policy of the state is to accord equal freedom of religious association to Kenyans. Like the United States Constitution, the objective of the Kenyan Independence Constitution was not to promote one religious conviction at the expense of others, but to provide an enabling environment for all creeds, thereby demonstrating that religion is respected by the Kenyan state. The intention of this policy was to separate religion from the politics of the country and to confine it as a private matter, outside the scope of state legislation or policy. Based on these provisions of the Independence Constitution, if the state supports the religious activities of a particular group, then it is interpreted as a violation of the Constitution.

Nevertheless, attempts to separate religion and state in Kenya have not entirely succeeded, as there is official public visibility of religion in Kenya, for instance the country's national anthem opens with the words "Oh God of all creation", and the opening ceremony of every parliamentary session or national public event is preceded by prayers offered by the representatives of the various religious groups. It is common that when the president, members of parliament, judges and other constitutional officers take the oath of office, they hold the

13 Hallencreutz CF and Westerlund D. 1996. "Anti-Secularist Policies of Religion", in Westerlund D (ed). Questioning the Secular State: The Worldwide Resurgence of Religion in Politics. New York: St. Martin's, 3.

14 Hallencreutz, and Westerlund, "Anti-Secularist Policies of Religion", 3.

15 Laws of Kenya: The Constitution of Kenya. 2001. Nairobi: Government Printers.

16 Kuru, "Passive and Assertive Securalism", 568-595. 
Bible or the Quran, depending on their religious affiliation, and add the words "so help me God" at the end of the oath. There have also been instances when the government has had to withdraw certain public policies and legislation for fear of antagonising a particular religious group. ${ }^{17}$

This illustrates that religion in Kenya is respected and ultimately plays a significant role in the public and political life. Despite its secular status premise, Kenya is intensely apprehensive about religion and regulates it on various levels. Therefore, within the Kenyan context, "the old ideas of the separation of church and state ... do not signify the separation of religion from politics."18 Despite the implicit claim in the Independence Constitution that Kenya is a secular state constitutionally, one never fails to notice the presence of religion in government policies and state functions. It is this reading of the relationship of religion and politics that informs my analysis on the debate of the Kadhi Courts and whether their inclusion in the Independence Constitution and the Bomas Draft Constitution contravenes the secular state premise.

\section{KADHI COURTS IN THE KENYAN INDEPENDENCE CONSTITUTION}

Before the introduction of the colonial administration, the Kenya coast was under the rule of a political model partially inspired by Islam and administered by the Sultan of Zanzibar. In Kenya, the Zanzibari hegemony covered the cities of Mombasa, Malindi and Lamu, together with parts of Sabaki North Bank, Chonyi, Kauma, the Bajun area south of Kiunga and parts of Digo. ${ }^{19}$ Under the rule of Seyyid Said bin Sultan (1806-1856), the Zanzibari hegemony extended its realm of influence, and by the end of eighteenth century the sultanate had emerged as a dynastic kingdom with an Arab (or Muslim) at the top. ${ }^{20}$ Although Seyyid Said exercised little direct control, his agents were established along the whole of what is now the Kenya coastline. ${ }^{21}$ Thus, coastal Kenya had a long tradition of sultanate rule prior becoming a British protectorate. Before Seyyid Said shifted the capital to Zanzibar, the sultanate was based in Oman, where it had grown out of the original Ibadi imamate. ${ }^{22}$ According to the Ibadi Muslims

17 Due to strong opposition and to avoid conflict with the religious communities, the Kenya government have on different occasion been forced to drop certain public policies. These unpopular policies included recognition of abortion and homosexuality, as well as the regulation of religious bodies in the country.

18 Voll JO. 1982. Islam, Continuity and Change in Modern World. Essex: Longman, 276.

19 PC/COAST/1/22/22, Kenya National Archives.

20 Mazrui AA. 2002. "The Triple Heritage of the State in Africa", in Laremont RR and Seghatolislami TL (eds). Africanity Redefined: Collected Essays of Ali A. Mazrui, Vol. 1. Trenton, NJ: Africa World, 37-138.

21 The Kenya Coastal Strip, Report of the Commissioner, December 1961.

22 The Ibadi (Ibadiyya) is a subsect of the Kharijite Islam that is neither Sunni nor Shi'a, and exists mainly in Oman, Zanzibar, Tripolitania in Libya, Mzab in Algeria and Jerba in Tunisia. The righteous imamate is a significant subject in Ibadi legal literature, which considers the Imam as a pious person who is chosen into the leadership position by the elders of the community, who are also obligated to 
their political system was viewed as an imamate, and the sultanate was actually a concession to Ottoman traditions of government in the eleventh century. ${ }^{23}$ The Ibadi imamate ensured that the religious community was politically established, providing for an intimate interaction between religion and politics.

However, in the eleventh century, internal reforms facilitated changes into the Oman imamate that included transition in the highest political office from imam to sultan. With the changes the sultan's office assumed a purely political position and delegated the religious duties to another office. ${ }^{24}$ Although a clear separation of mosque and state evolved in Oman, the sultan retained most of the prerogatives that had formerly been the privilege of the imams. For that reason, when the Oman sultanate ultimately established its base in Zanzibar, efforts were made to maintain the same political system. Therefore, the liwali and kadhi systems of administration were introduced in the Zanzibar sultanate to represent the sultan in various capacities. ${ }^{25}$

The end of the nineteenth century, during the rule of Sultan Barghash (18701888), brought the transition from precolonial Arab Muslim hegemony to Arab Muslim dominance under colonial overlordship. During this period, the British policy of indirect rule used the native institutions of government as means to exert colonial control. The colonial administration was reluctant to tamper with local native institutions that had recognised their authority, preferring to use those institutions instead of inventing new ones. ${ }^{26}$ Following this arrangement, freedom of religion was guaranteed, though no extra effort was made to encourage Islam. Supposedly, at least, the British colonial power respected Muslim sensitivities in so far as religious practices were concerned. This was evident with the recognition of the sultan's administrative and legal institutions. A clear illustration of this recognition is evident in a report by a British colonial officer, Commissioner James W Robertson (1899-1983):

Within the administration there is a special cadre of Arab administrative officers [read also Arab Muslims] headed by the Liwali for the Coast (who is also Adviser on Arab affairs to the Governor) and consisting, apart from him, of four Liwalis and ten Mudirs. These officers also had subordinate Courts of the second and third class with jurisdiction

depose him if he acts unjustly. The last "true Imam" to unite the entire country of Oman under his power was Ahmad ibn Sa'id (ruled 1754-1783 CE), the founder of the BuSa'idi dynasty. His descendants later took the title not of Imam, with its connotations of religious leadership, but Seyyid, an honorific title held by any member of the royal family. Later, they used the title Sultan, implying purely coercive power.

23 Pouwels RL. 1979. Islam and Islamic Leadership in the Coastal Communities of Eastern Africa, 1700 to 1914. London: University Microfilms International, 363.

24 Pouwels, Islam and Islamic Leadership, 394.

25 The Kadhi were judges expected to interpret the Islamic law (sharia) in the religious courts on behalf of the Sultan, while the Liwalis were governors administering specific areas of the coastal region with authority from the Sultan.

Mazrui, "The Triple Heritage of the State in Africa", 37-138. 
in both civil and criminal cases. There are, in addition, Kadhis who are magistrates specialising in questions of Islamic law in relation to inheritance, marriage and divorce, and other personal matters. Jurisdiction is limited to Arabs, Somalis and Africans [Muslims]. These posts were in existence before British administration and to the Muslim peoples of the Coast they are, on nationalist, religious and historical grounds, of very great importance. ${ }^{27}$

However, all the three Arab officials, liwalis, mudirs and kadhis, were not appointed by the sultan, who was also not consulted in their appointments. ${ }^{28}$ This Arab cadre of officers was now on the payroll of the colonial administration. Since, for instance, in the precolonial period, the kadhis were expected to interpret the Islamic law as judges on behalf of the sultan, this was retained for continuity and smooth transition.

Immediately, the colonial administration took over the governorship of the sultan's dominion, it initiated a number of changes that had far-reaching implications. The changes started with the promulgation of East Africa Order in Council of 1897, which entrenched British rule, as it legally established institutions of state, power and authority. The Order in Council established the Legislative Council, which in turn enacted the Native Court Regulation that empowered colonial officials to make rules and regulations for the administration of natives. The Native Courts Authority (1897) established the Native Courts Ordinances (NCO) that contained statutes like the liwali, mudir and kadhi courts ordinances. ${ }^{29}$ After the establishment of the NCO, the Legislative Council enacted the Mohammedan Marriage Divorce and Succession Ordinance 1897, which institutionalised selected aspects of Muslims personal law, such as marriage, divorce and succession. The unfolding events indicated the colonial authority's eagerness to fulfill the agreement made between Zanzibar and Britain. In the agreement, the British had promised to continue recognising the authority of the religious institutions in the protectorate. It was the sultan's wish that "all affairs connected with the faith of Islam will be conducted to the honour and benefit of religion, and all ancient customs will be allowed to continue." 30

27 The Kenya Coastal Strip, Report of the Commissioner, December 1961.

28 The Kenya Coastal Strip, Report of the Commissioner, December 1961.

29 Mwakimako HA. 2006. "The Ulama and the Colonial State in the Protectorate of Kenya: Appointing Shaykh al-Islam Sharif Abd-al-Rahaman b. Ahmad Saggaf (1884-1922) and Chief Kadhi Shaykh Muhammad b. Umar Bakore (c.a.1932)", in Loimeir R and Seesemann R (eds). The Global Worlds of the Swahili. Hamburg: LIT.

30 The Kenya Coastal Strip, Report of the Commissioner, December 1961. 
After independence in 1963, the constitutional status of the Kadhi Courts could be found in Article 66 (1) to (5), which provided for their establishment. Specific articles on the Kadhi Courts in the Independence Constitution stated:

Article 66 (1)

There shall be a Chief Kadhi and such number, not being less than three, of other Kadhis as may be prescribed by or under an Act of Parliament.

Article 66 (5)

The jurisdiction of a Kadhi's court shall extend to the determination of questions of Muslim law relating to personal status, marriage, divorce or inheritance in proceedings in which all the parties profess the Muslim religion.

At independence, the Kadhi Courts were three in number, but in 1967 the Kadhi Courts Act allowed the establishment of the courts in other parts of the country, and the number of the courts subsequently increased. Today, the Kadhi Courts are scattered and can be found in all the major towns in the country. According to the Independence Constitution, these courts are to be presided over by either a Chief Kadhi, or a Kadhi appointed by the Judicial Services Commission. It also outlined the jurisdiction of the courts over issues related to personal status (marriage, divorce and inheritance) in which the individuals involved practised the Islamic faith. In the early 2000s, during the debate over a new constitution, the Bomas Draft Constitution that emerged retained the provision entrenching the Kadhi Courts, to the dissatisfaction of the opposing churches. Passionate and emotional campaigns supporting and opposing the courts emanated from both the Christian and Muslim sides. It was a debate that, to a certain extent, polarised the country.

\section{THE BOMAS DRAFT BILL CONSTITUTION AND THE RETENTION OF THE KADHI COURTS}

After more than three decades of independence, Kenya began a search for a new constitution. The Independence Constitution was alleged to have allowed the suspension of human rights in many circumstances and also to have permitted a range of oppressive laws to continue. There was the feeling among many Kenyans that the laws in the Independence Constitution were similar to those used by the colonial government to oppress Kenyans and were no longer relevant in postcolonial Kenya. Despite the numerous amendments to the Independence Constitution, there were increasing calls for its complete overhaul. ${ }^{31}$ As the clamour for constitutional reform reached a climax, the government insisted that the drafting of such an important document was a

31 Okondo PH. 1995. A Commentary on the Constitution of Kenya. Nairobi: Phoenix. 
task that was best done by foreign experts. ${ }^{32}$ Reform advocates disagreed with the government, however, arguing that foreign experts could not offer solutions to local problems and demanding that the process to be driven by the people in order to be to be valid.

This is the constitution that its advocates referred to as the Wanjiku Constitution. Wanjiku is a common Kikuyu female name, and like elsewhere in Africa, the female in Kenya is often the most underprivileged person in society. The name Wanjiku was borrowed to symbolise the common person in the country. The call for a Wanjiku Constitution implied a constitution where the ordinary citizens of the country were consulted about the type of government they desired. Consequently, in 1998, the Constitution of Kenya Review Commission (CKRC) was established, and was charged with the responsibility of collecting views of Kenyans on what they would want reflected in the new constitution. The commission endeavoured to hear as many voices as possible to ensure that the recommendations they made were representative of the common person. On 27 September 2002, the CKRC unveiled a Draft Bill that came to be popularly known as the Bomas Draft Bill Constitution. Upon publication of the CKRC's Draft Bill, a group of Christian churches highlighted a number of issues that were of concern to them in the draft constitution, most notably the entrenchment of Kadhi Courts abortion and same-sex marriage. ${ }^{33}$

In the Bomas Draft Bill Constitution, the Kadhi courts were retained and additional changes incorporated based on Muslim recommendations. The provisions on Kadhi Courts in the Bomas Draft Bill were as follows:

Kadhi courts:

Article 199

(1) There are established Kadhi's Courts, the Office of Chief Kadhi, Office of Senior Kadhi and the Office of Kadhi.

(2) There shall be a number, being not less than thirty, of other Kadhis as may be prescribed by the Act of Parliament.

(3) A Kadhi is empowered to hold a Kadhi's court called a District Kadhi's Court, having jurisdiction within a district or districts as may be prescribed by, or under an Act of Parliament. ${ }^{34}$

32 Owino RL. 2003. "Whose Constitution will it be, finally?", Daily Nation, 11 December:5.

33 Musibi P. 2004. "How the Kenya Church got Involved in the Constitutional Process", The Eagle, August:8.

34 See the Draft Bill, The Constitution of the Republic of Kenya, 27 September 2002. Online at: http://www.ogiek.org/sitemap/constitution-kenya.pdf 
Jurisdiction of Kadhi courts:

Article 200

(1) The Jurisdiction of a Kadhi's court extends to (a) the determination of questions of Muslim Law relating to personal status, marriage, divorce, including matters arising after divorce, and inheritance and succession in proceedings in which all the parties profess Islam; (b) the determination of civil and commercial disputes between parties who are Muslims, in the manner of a small claims courts as by law established, but without prejudice to the rights of parties to go to other courts or tribunals with similar jurisdiction; (c) the settlement of disputes over or arising out of the administration of $w a k f^{35}$ properties $^{36}$.

With respect to the Kadhi Courts sections of the Bomas Draft Bill, Muslims had recommended that the existing Kadhi Courts be reformed and made efficient. Some of the recommendations that were incorporated into the Bomas Draft Bill, such as Article 202, included the requirement that Kadhis be trained in both Islamic and common laws. In addition to their Islamic credentials, the Kadhis were required to be experienced advocates with a common law degree. Also recommended was the provision for a Kadhi Court of Appeal to address appeals from the lower Kadhi Courts. The draft pointed that only after these appeals have passed through the Kadhi Court of Appeal would cases from the lower Kadhi Courts be heard in the national High Court of Appeal. And lastly, the Bomas Draft Bill Constitution recommended that the jurisdiction of the Kadhi Courts be expanded to hear minor commercial disputes among Muslims. ${ }^{37}$

When these recommendations were published in the Bomas Draft Bill of the CKRC, they raised concern among Christians, particularly those drawn from the Anglican and Pentecostal churches. Their opposition in the plenary was uncompromising. The controversy instigated an intense debate between Muslims and Christians over religion and state. Following the unresolved discussion in the plenary, the chairman of CKRC called a meeting of Christian, Muslim and Hindu leaders to find ways of resolving the impasse. The meeting agreed to appoint a committee charged with the responsibility of solving the issue amicably. After several meetings, the committee accepted a number of amendments that Muslim representatives refused to endorse. While Muslims insisted on having the Kadhi Courts entrenched in the constitution, the church

35 Wakf (or waqf) is any valuable (non-)item that an individual voluntarily cedes private ownership and consecrates it to God through a management system that holds it in trust during which period its value would be improved, sustained, and appropriated for the specified objective(s) in the service of God.

36 See the Draft Bill, The Constitution of the Republic of Kenya, 27 September 2002.

37 See sections 200, 201 and 202 of the Draft Bill, The Constitution of the Republic of Kenya, 27 September 2002. 
led opposition wanted the entire institution of the Kadhi Courts removed from the Bomas Draft Bill Constitution. ${ }^{38}$

Leading this opposition was a group of church clergies who identified themselves under the banner of the Federation of Churches in Kenya, or simply the Kenya Churches. The demand by the Christian clergy for the abolition of the Muslims courts was based on the following provisions in the Bomas Draft Bill of the Constitution:

State and Religion

Article 10

(1) State and religion shall be separate.

(2) There shall be no state religion.

(3) The state shall treat all religions equally. ${ }^{39}$

According to the opponents of the Kadhi Courts, the Bomas Draft Bill had provided that Islamic personal laws would be a source of laws in Kenya despite the provisions in Article 10. They argued that Islamic laws are religious laws and thereby contradict the three provisions stated in Article 10. They further pointed that the Bomas Draft Bill had created a parallel judicial system for Muslims, which was tantamount to favouring one religion and contravened the principle that the state should treat all religions equally. This line of argument was to reappear many times during the debate, and it became the basis of reference for the opponents of the Kadhi Courts.

In this regard, the group of clergies requested all provisions on the Kadhi Courts be removed and replaced by a provision establishing subordinate courts with limited jurisdiction on issues of personal laws relating to marriage, divorce and inheritance, between parties of the same religious faith or persuasion and who submit to that jurisdiction. ${ }^{40}$ Consequently, the proposed provision by the opposing churches would allow the Parliament of Kenya to establish subordinate courts for any religious community, including Muslims, to deal with their personal laws if so desired. This approach, in their view, would ensure equal treatment of all religions.

After a wide debate at the constitutional review conference, three issues related to the Kadhi courts were removed. These were: (1) the provision on Islamic laws being a source of laws in Kenya, (2) the creation of a parallel judicial system for Muslims, and (3) determination of civil and commercial disputes according to Islamic law. This implied that the provision entrenching the Kadhi Courts in the Bomas Draft Bill Constitution would be retained, to the dissatisfaction of the

38 2003. "The Kenya Church: The Federation of Churches in Kenya", Daily Nation, 15 September: 15 .

39 See section 10 of the Draft Bill, The Constitution of the Republic of Kenya, 27 September 2002.

40 Musibi, "How the Kenya Church got Involved”, 8; 2003,“The Kenya Church”, 15. 
opposing churches. As a result, in July 2004, twenty-six applicants representing a group of Kenyan churches went to the High Court over the entrenchment of the Kadhi Courts in the Independence Constitution and the Bomas Draft Bill Constitution. ${ }^{41}$ The federation argued that the historical reasons for which the Kadhi Courts were given constitutional protection are no longer tenable. They claimed that after several years of independence, the former "subjects" of the sultan of Zanzibar should no longer require any constitutional protection, as Kenya was now a unified sovereign state where all enjoyed equality irrespective of race, gender, or religion. ${ }^{42}$ They contended that the entrenchment of the Kadhi Courts in the Bomas Draft Bill and the Independence Constitution was a step towards introducing sharia in Kenya, which was unacceptable, in their view. They also pointed that any financial maintenance of the Kadhi Courts from the public resources was unjust and amounted to development of one religion. They interpreted this practice as Islam being declared a state religion, contradicting the provision in Article 10 that there shall be no state religion.

Therefore, they wanted Section 66 of the Independence Constitution, which they argued introduced and entrenched the Kadhi Courts to be declared unconstitutional and expunged from the Bomas Draft Bill. ${ }^{43}$ In responding to the argument raised by the Federation of Churches of Kenya, the Muslims insisted that the inclusion of Kadhi Courts in the Independence Constitution was not because the beneficiaries were merely "subjects" of the sultan of Zanzibar, but because the courts are a core institution in the practice of Islam. Muslims claim that the laws, rules and regulations applied by the Kadhi Courts are not a creation of the sultan of Zanzibar, but a product of the teachings of Islam. In their view, the Muslims felt insulted by the claim that the courts are outdated and have no place in a modern constitution. ${ }^{44}$ Six years later, when an application was submitted in the Constitutional Court challenging the legality of the Kadhi Courts, the judges presiding over the case gave their verdict, declaring the Kadhi Courts to be unconstitutional.

\section{THE SECULAR STATE PREMISE AND THE CONSTITUTIONALITY OF THE KADHI COURTS}

In 2004 a section of church leaders had sought several declarations in the High Court with regard to the entrenchment of the Kadhi Courts in the Independence

41 Nyamboga N. 2004. "Clerics sue over Kadhis' Courts", East African Standard, 15 July: 11.

42 2009. "Constitution Review: Experts should be Honest to Issues Agreed Upon in the Previous Process", The New Dawn, 1 June-1 July:4, 7.

43 Nyamboga, "Clerics sue over Kadhis' Courts", 11.

44 "Constitution Review: Experts should be Honest to Issues Agreed Upon in the Previous Process", 4, 7. See also the High Court Judges Nyamu JG, Wendo RVP and Anyara Emukule MJ. "Judgement". Online at: http://www.nation.co.ke/blob/ view/-/924724/data/162900/-/m44lw9z/-/Kadhi+Ruling.pdf 
Constitution. The judges presiding over the case declared the Kadhi Courts to be illegal and unconstitutional in May 2010. In their verdict, the judges concluded:

(1) In view of the discussion above, we grant the declarations sought in prayer 1 limited to declaring that section 66 is inconsistent with sections 65 and 82 and in respect of section 82 is discriminatory to the applicants in its effect.

(2) As regards to paragraph 2 of the prayers, we find and hold that sections 66 and 82 are inconsistent with each other, and that section 66 is superfluous but it is not the court's role to expunge it. It is the role of Parliament and the citizenry in a referendum.

(3) As regards prayer 3, we hold and declare that any provision similar to section 66 in any other draft of a constitution in word or effect is not ripe for determination.

(4) The enactment and the application of the Kadhis' courts to areas beyond the 10 miles coastal strip of the Protectorate is unconstitutional. ${ }^{45}$

Following the High Court's verdict on the Kadhi Courts, their judgment was received differently and widely debated by various sections of the Kenyan population. For their, part the church leaders welcomed the ruling and urged the government to implement it. ${ }^{46}$ The government through the attorney general termed the verdict unconstitutional and appealed to the High Court challenging the ruling. ${ }^{47}$ And for the Muslims, a section of the community went to court to challenge the ruling declaring the Kadhi Courts illegal and unconstitutional. The petitioners were aggrieved by the decision of the court claiming their constitutional rights had been violated. They argued that the Kadhi Courts provided an essential dispute resolution mechanism, without which a vacuum would be created in administering justice. Through their lawyer the Muslims argued: "If the effect of the judgment would be to disband Kadhi Courts, which is a section of the judiciary established by the Constitution of Kenya, it would disrupt their proceedings thus creating a sense of insecurity and disillusionment with the administration of justice for a large sector of the population." ${ }^{48}$ Muslim leaders rejected the view that the Kadhi Courts are discriminatory on the basis of Section 62 of the Independence Constitution. They claimed that the ruling was faulty and that the judges had ignored the provisions of the same section they had quoted, which said that issues of divorce, adoption, marriage and inheritance are excluded from the definition of discrimination. ${ }^{49}$ As illustrated

45 2010. "Judges' Ruling that Threw Cold Water on Draft", Daily Nation, 26 May:9.

46 Benyawa L. 2010. "Muslim Challenge Ruling on Kadhi Courts", The Standard, 4 June:7.

47 Benyawa, "Muslim Challenge Ruling on Kadhi Courts", 7.

48 Benyawa, "Muslim Challenge Ruling on Kadhi Courts", 7.

49 "Judges' Ruling that Threw Cold Water on Draft". 
earlier, Section 66 of the Independence Constitution gave the Kadhi Courts the jurisdiction to deal with matters of personal law among Muslims.

The main foundation of the judges' ruling was that Section 66 of the Independence Constitution (which allows for the creation of the Kadhi Courts) is inconsistent with Section 65 (which gives parliament the power to establish courts subordinate to the High Court) and Section 82 (which outlaws discrimination in law making) thereby declaring Section 66 to be superfluous. Despite making the correct conclusion that the role of the court is to interpret the law, and not to amend it, their verdict seem to have been the opposite. They made categorical pronouncements that declared a section of the Independence Constitution illegal. For instance, they granted the request, which had sought for Section 66 to be declared discriminatory, oppressive, unconstitutional, and null and void.

However, the attorney general argued that the High Court had no jurisdiction to declare Section 66 of the Independence Constitution as being unconstitutional. His position was that Section 66 of the Constitution was an existing provision and could not be struck out on the basis that there is no provision of the constitution that is superior or inferior to the other. For the constitutional court to nullify any provision of the constitution would itself be unconstitutional. According to the attorney general, the court's jurisdiction would be to strike out a law (ie. Act of Parliament) other than a provision of the constitution. ${ }^{50}$ Consequently, it was wrong to declare the Kadhi Courts illegal if the Independence Constitution provided for them. In their pronouncement, the judges emphasised that they had made a declaration that religious courts should not form part of the judiciary, as this would offend the doctrine of separation of state and religion.

The High Courts' decision was clear advocacy for "assertive secularism", a form of secularism that intends to eliminate any symbol and expression of religion from the public sphere. According to the judges, secularism implies lack of religiosity and therefore, the absence of religious authorities. The interaction of religion and politics is a subject that has been widely debated by scholars. While not reaching a definite position on the subject the High Court dealt with the issue as if there were a conclusive position in the international law. Countries that allow the interaction of religion and politics have embraced different approaches peculiar to their unique situation.

According to Ahmet Kuru, "state policies toward religion are the result of ideological struggles", which manifests in competition between "passive secularists" and "assertive secularists." 51 "Passive secularism", in Kuru's description, is a political principle that attempts to uphold state neutrality toward various religions, thereby allowing for the public visibility of religion: whereas "assertive secularism" is a "comprehensive doctrine" that intends

50 Kamau NG. 2010. "Religious Courts go Against the Secular Nature of the State", Daily Nation, 7 June:11.

51 Kuru, "Passive and Assertive Secularism", 568-595. 
to purge religion from the public sphere. ${ }^{52}$ Due to the realisation that it is difficult to have a complete separation of religion and politics, countries that regards themselves as secular states, including Kenya, have grappled with the question of the extent this interaction should be accepted. Therefore, the Kadhi Courts were provided for in the Independence Constitution under the peculiar historical circumstances of the moment, which its defenders have argued should be put into consideration when debating about them.

The High Court judges also held that the enactment and application of the Kadhi Courts beyond the ten-mile coastal strip specified in their establishment to be unconstitutional. This judgment attempted to limit the Kadhi courts to the ten-mile strip whose expansion outside the strip was sanctioned by an act of Parliament. In light of this, the High Court knew they had the jurisdiction to declare illegal any law made by an Act of Parliament if it is in conflict or inconsistence with the constitutional provision. Nevertheless, it was necessary for the judges to examine the history of the Kadhi Courts before giving such a verdict. Though the Kadhi Courts were mostly associated with the coastal region, during the colonial period, the British had recognised the importance of this institution and extended it outside the ten-mile strip. This was illustrated by the British appointing the first state funded Kadhi for the Somali Muslims of the North Frontier District (NFD) in 1927..$^{53}$

During the early years of the first president of Kenya, the expansion of the Kadhi Courts to the Somalis of the NFD was used as one of the conditions in ending the Shifta War. ${ }^{54}$ As part of the peace agreement brokered in Arusha by Zambia's President Kenneth Kaunda in 1967, the government of Kenya accepted the expansion of Kadhi Courts to the residents of the NFD. ${ }^{55}$ The decision was significant in pacifying the Somalis' agitation to secede as it made them feel that their religious and cultural welfare was taken into consideration by the postcolonial government of Jomo Kenyatta. This is an important part of the background that should have informed the decision of the judges. Other analysts argued that at minimal, the expansion of the Kadhi Courts should have been informed by the justification that "Kenya is not a federal state and that it will be wrong to expect a citizen to enjoy a right in Mombasa and not have the same right in other parts of the country." 56 This view implies that Muslims

52 Kuru, "Passive and Assertive Secularism".

53 Kerrow B. 2010. "Are some of our Churches Playing the Devil's Advocate", The Standard, 30 May:16.

54 When the Somalis of the NFD were denied their desire to secede and join the Republic of Somalia, they resorted to armed resistance to sabotage the Jomo Kenyatta leadership (1963-1978). Through the support of the Somilia government, the Kenya's Somalis uprising which came to be known as the Shifta insurgency was fought in sporadic ways by employing a guerrilla tactic warfare that targeted government convoys and personnel.

55 Kerrow, "Are some of our Churches Playing the Devil's Advocate", 16.

56 Muganda I and Biriq B. 2010. "Ruling on Kadhis' Courts was Judicial Impunity", The Standard, 2 June:15. 
in Kenya also live outside the ten-mile strip, and it is the responsibility of the government to ensure that they continue enjoying their rights as Muslims wherever they choose to live. On the issue regarding financial maintenance of the Kadhi Courts by the government, the High Court declared that it is discriminatory and sectarian. Such a conclusion was informed by perceiving the Kadhi Courts as religious courts and not part of the judiciary. According to the Independence Constitution, the Kadhi Courts form an integral part of the official judiciary, and this is why the public coffers are used to fund and maintain them, their proponents hold. Undoubtedly, the ruling by the judges against the Kadhi Courts set off a religious tension threatening the MuslimChristian relations in Kenya.

\section{CONCLUSION}

The debate over the Kadhi courts revolves around the question of whether the courts should be entrenched in the Kenyan constitution or not. Opponents of the Kadhi Courts, chiefly a section of Christian church leaders, claim to have embraced the ideal of secular state against the adoption of religious laws. On the other hand, the supporters of the Kadhi Courts, most of whom are Muslim, are oblivious to the implications of religious laws in the national context characterised by pluralism and freedom of expression. Nevertheless, the Kadhi Courts saga has at the moment been resolved. In August 2010, Kenyans voted for a new constitution that entrenches the Kadhi Courts as part of the judicial system. The passing of the 2010 Constitution of Kenya in a referendum illustrated support for the Kadhi Courts by most Kenyans. Amidst opposition from a section of church leaders, the referendum results showed that there was acceptance of the Kadhi Courts in the country as stipulated in Section 170 of the 2010 Constitution. ${ }^{57}$

Therefore, this chapter has demonstrated that the Kadhi Courts have a long history in Kenya. Despite the adoption of the secularity principle in the Kenyan Constitution, the Kadhi Courts have been accepted as part of the country's legal system. Consequently, the entrenchment of the Kadhi Courts did not contravene the secular state premise in the Kenyan Constitution since the form of secularism observed in the country is not anti-religious, but rather values the role of religion in formulating public policies. There is need for more public awareness of the Kadhi Courts to guard against future opposition to them, and possibly challenge the idea that they are a threat to the secular state premise in Kenya. Clearly, secularism is not purely about the absence of religion, and there is also no single ingredient of a secular state since secularism is a social category, containing numerous dimensions.

57 The Constitution of Kenya. 2010. Nairobi: The Government Printer. 